"This is the peer reviewed version of the following article: Calvo Sorando, José Pedro y Rodríguez Pascua, Miguel Angel y Martín Velázquez, Silvia y Jiménez, Sergio y Vicente Muñoz, Gerardo de (1998) Microdeformation of lacustrine laminite sequences from Late Miocene formations of SE Spain: an interpretation of loop bedding. Sedimentology, 45 . pp. 279-292. ISSN 0037-0746, which has been published in final form at https://doi.org/10.1046/j.1365-3091.1998.00145.x. This article may be used for non-commercial purposes in accordance with Wiley Terms and Conditions for Use of Self-Archived Versions."

\title{
Microdeformation of lacustrine laminite sequences from Late Miocene formations of SE Spain: an interpretation of loop bedding
}

\author{
JOSE P. CALVO*, MIGUEL RODRIGUEZ-PASCUAt, SILVIA MARTIN-VELAZQUEZt, \\ SERGIO JIMENEZ* and GERARDO DE VICENTEt \\ *Departamento de Petrología y Geoquímica, Facultad CC. Geológicas, Universidad Complutense, 28040 \\ Madrid, Spain (E-mail: jpcalvo@eucmax.sim.ucm.es) \\ tDpto. de Geodinámica, Fac. CC. Geológicas, Univ. Complutense, 28040 Madrid, Spain
}

\begin{abstract}
Lacustrine laminated sediments (laminites) present in Late Miocene formations of the H1jar Basin, SE Spain, display well developed loop bedding, a structure consisting of bundles of laminae that are sharply constricted at intervals, giving a morphology of loops or links of a chain. The laminite sequences, which are interbedded with turbidite marlstones, were accumulated on the bottom of a permanently stratified lake developed in a rapidly subsiding basin limited by $010^{\circ}$ and $105^{\circ}$ normal faults. As deduced from both macro- and microdeformational analyses, the basin evolved under an extensional stress field throughout the Late Miocene. Four main types of loops, simple and complex loops with subcategories, have been recognized within the laminite sequence. Simple loops of type 1 show the best definite pattern, quite similar to 'pinch and swell structures', a type of boudinage typical of stretching of alternating beds where the competence contrast is not strongly marked. The remaining loop types display contortion and occasional breakage of laminae (microfaulted edges) indicative of microdeformation near the boundary between the ductile-brittle deformational fields. The distribution of the various loop types across the laminite sequence reflects an interplay between progressive lithification of the laminites as sedimentation progressed and tectonic stresses which affected the sediment sequence. Accordingly, a mechanism of deformation under an extensional stress field, ultimately related to the creep movement of the main basin faults which resulted in successive seismic shocks of low magnitude, is proposed to explain the formation of loop bedding in the laminites.
\end{abstract}

\section{INTRODUCTION}

Loop bedding consists of 'small groups of laminae that are sharply constricted or that end at intervals, giving the effect of long, thin loops or links of a chain' (Bates \& Jackson, 1980). This type of bedding has been occasionally recognized in finely laminated sediments, especially in lacustrine laminite sequences accumulated in both recent and ancient lake environments. Moreover, loop bedding is also present in laminated deepsea facies as, for instance, the diatomaceous deposits from the Miocene Monterey Formation,
California (Ozalas et al., 1994). Bradley (1931), Cole and Picard (1975) and Dean and Fouch (1983) have described oil-shale deposits displaying loop bedding from the Eocene Green River Formation, western USA. The presence of loop bedding has also been reported from finely laminated open lake facies of the Devonian Orcadian Basin (Rayner, 1963; Donovan, 1975; Trewin, 1986; also personal commun. by J. Parnell, 1995). Gibling et al. (1985) have illustrated loop structures developed in Miocene deep lake sediments of Thailand but the authors did not offer any interpretation of this feature. In 
recent sediments, loop bedding has been recognized within the Holocene sedimentary record of Lake Van, Turkey, and Great Salt Lake, Utah (K. Kelts, personal commun., 1995). Besides these occurrences of loop bedding in lacustrine laminite sequences, Hesselbo and Trewin (1984) have described similar structures, that they named 'pull-apart structures', in laminated dolomites and mudstones from the Lower Carboniferous of Scotland. According to these authors, the laminated sediments were deposited in a thermally stratified freshwater lake or a brackish lagoon.

Despite the relatively frequent recognition of loop bedding in lacustrine laminite sequences, the pattern of formation of this structure remains controversial. Several interpretations have been suggested, including (i) desiccation cracks (Bradley, 1931), (ii) synaeresis cracks (Donovan \& Foster, 1972; Cole \& Picard, 1975), (iii) deformation related to extensional stress, as deduced from the descriptive term 'boudinage-like pull-apart structures' in Dean and Fouch (1983, their Fig. 32), (iv) seismically-induced structures (Hesselbo \& Trewin, 1984), (v) distortion due to the shear stress produced by turbidite currents on the underlying sediment (Trewin, 1986). Moreover, disruption of the lamination by gas bubble leakage may also result in structures that are somewhat similar to loop bedding (FregenalMart1nez \& Meléndez, 1994).

Whichever the exact mechanism of formation, it seems to be current consensus that loop bedding must be considered a type of deformational structure ultimately related to tectonic stresses affecting finely laminated, unlithified or poorly lithified sediments, especially those accumulated in lake basins. In this paper we present a case study of loop bedding occurrences from Late Miocene lacustrine laminite sequences deposited in extensional basins of the Prebetic area, SE Spain. The lacustrine laminite sequences displaying well-developed loop bedding are present at several levels of the Late Miocene formations. A very well-exposed outcrop in the H1jar Basin has been selected for careful observation and analysis of this type of structure. The results derived from this case study could provide a solid basis for the interpretation of loop bedding developed in finely laminated sediments elsewhere and contribute to a better understanding of some deformational features related to the transmission of tectonic stresses through unlithified sediments. The occurrence of loop bedding in sedimentary sequences is also considered to be relevant in providing insight about the sedimentary-tectonic relationships accounting for their accumulation.

\section{GEOLOGICAL AND SEDIMENTOLOGICAL CONTEXT}

During the Late Miocene, several continental basins were formed in the external side of the Betic Chain, the so-called Prebetic Zone, in SE Spain (Sanz de Galdeano \& Vera, 1992) (Fig. 1A). The basins display varied extents, ranging from a few $\mathrm{km}^{2}$ (H1jar Basin) to $250 \mathrm{~km}^{2}$ (Las MinasCamarillas Basin). The basins are typically elongate and formed as rapidly subsiding troughs during the Late Vallesian to Late Turolian (Tortonian-Messinian of the marine chronostratigraphic scale) (Bellon et al., 1981; Bellanca et al., 1989; Calvo \& Elizaga, 1994). Throughout this time interval, the basins were filled by terrestrial, mainly lacustrine sedimentary deposits reaching up to $500 \mathrm{~m}$ in thickness.

The lake basins are located in a tectonic transfer zone related to the emplacement of a major tectonic structure, the Cazorla-Alcaraz Arc, characterized by a system of imbricated thrusts (Fig. 1B). The study area is traversed by three main faults with NW-SE directions: Pozohondo, Lietor and Socovos-Calasparra faults. The two last faults delimit an area where the most important lake basins developed. The basins are bounded by E-W normal faults and their formation was likely related to an antiformal lithospheric flexure derived from the tectonic emplacement of the Internal Betic zone (Van der Beek \& Cloethingh, 1992).

The H1jar Basin is a very small $\left(\right.$ c. $\left.2 \mathrm{~km}^{2}\right)$, normal fault-bounded basin located to the south of the main Liètor Fault (Fig. 1C). Despite its reduced extent, the basin was filled by up to $470 \mathrm{~m}$ of terrestrial deposits that disconformably overlie Jurassic, Early Cretaceous and Middle Miocene marine formations. The basin is elongated $010^{\circ}$, both the western and eastern flanks of the basin being delimited by normal faults of the same direction which separate the continental deposits from the Mesozoic and older Miocene formations, mainly composed of carbonate materials.

Finely laminated lacustrine sediments account for more than two-thirds of the total thickness (about $300 \mathrm{~m}$ ) of the continental succession deposited in the basin throughout the Late Miocene. The lacustrine sediments overlie gravel and sandstone beds with occasional intercalated 

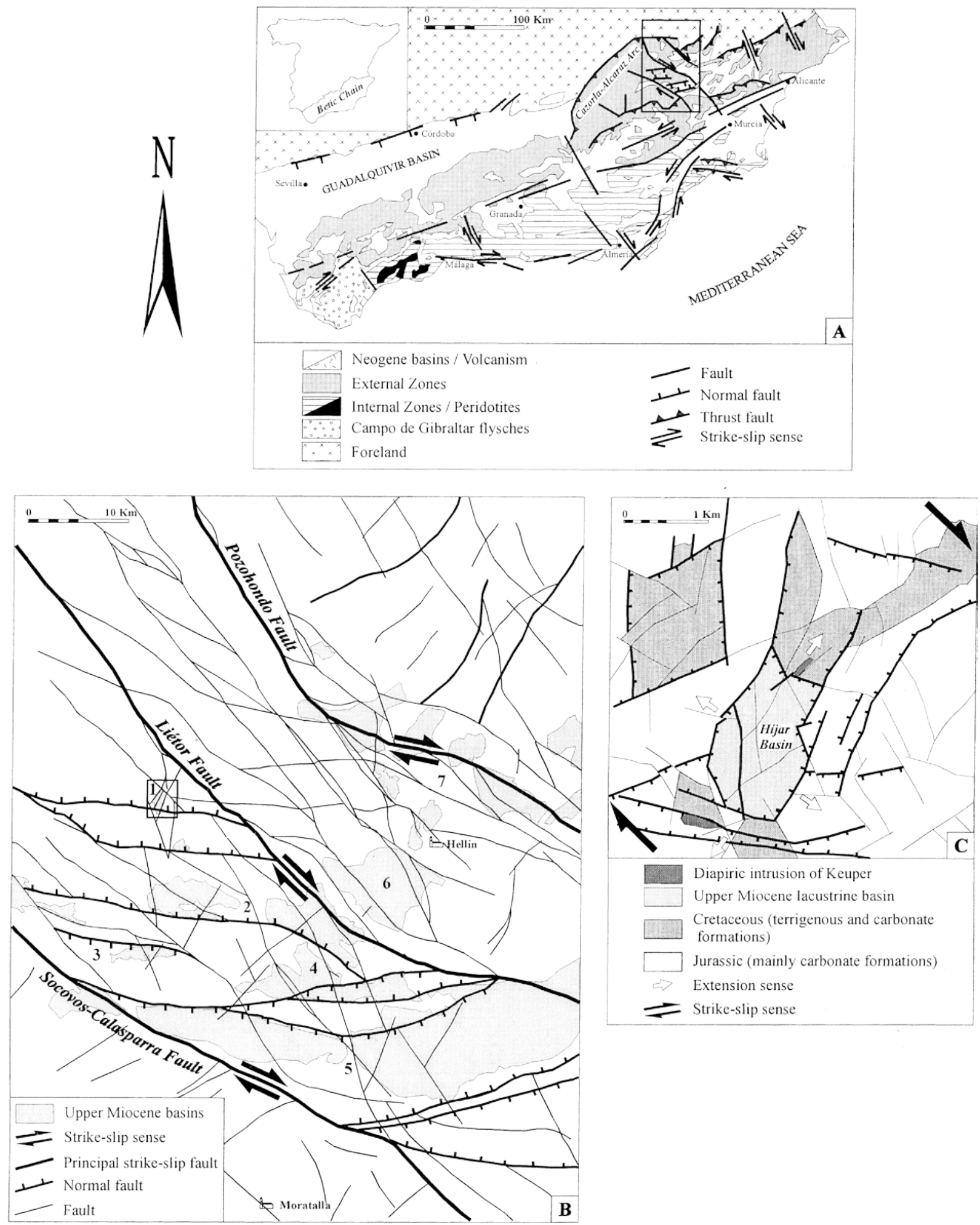

Fig. 1. Geological context of the study area. (A) Sketch map of the Betic Chain in southern Spain; boxed area encloses the region shown in 1B. (B) Principal structural elements of the eastern side of the Cazorla-Alcaraz Arc, Prebetic Zone, and location of the lake basins developed in the area throughout the Late Miocene: 1, H1jar; 2, Elche de la Sierra; 3, Gallego; 4, Cenajo; 5, Las Minas; 6, Hell'h; 7, Pozohondo. (C) Sketch geological map of the H1jar Basin showing the main faults that limit the basin; white arrows indicate the main extension directions that controlled the tectonic evolution of the basin through Miocene. 
carbonates that were deposited in a fluvio-lacustrine environment (Calvo et al., 1978; Elizaga, 1994). In its turn, the lacustrine succession is capped by a 20 m-thick sequence of sand and gravel beds which accumulated in a fan-delta environment.

The lacustrine sediments that form the bulk of the Tertiary succession consist mainly of an alternation of laminated marlstones and laminites with episodic thin (cm-thick) sandstone beds (Fig. 2). Locally, the laminites are highly indurated resulting in porcelanite, i.e. siliceous beds of moderate hardness, dull lustre and typical conchoidal fracture (Bates \& Jackson, 1980). Laminated marlstones constitute the most prominent lithofacies across the section. They are well-bedded and consist of centimetre-thick $(0 \cdot 5-20 \mathrm{~cm})$, flat-bottom beds usually displaying normal grading from occasional medium- to finegrained sandstone at the bottom to very fine detrital marlstone at the top. The marlstone is composed of a mixture of calcite crystals, diatom shells and minor clay grains. Intraclasts formed of laminite fragments (rip-up clasts) are often included in the basal parts of the marlstone beds, especially where the marlstone overlies laminite sequences. Dark layers, $1-3 \mathrm{~cm}$ thick, showing a huge accumulation of plant remains have been occasionally observed at the top of some marlstone beds. According to these features, the marlstones are interpreted as turbidites that were deposited by dilute mass flows on the lake floor (Sturm \& Matter, 1978; Buatois \& Mángano, 1995). The turbidite sediments, which account for a very high rate of the total sedimentary record of the lake basin during this period, alternate irregularly with packages of laminites of variable thickness which constituted the background sedimentation of the lake. The laminite packages comprise rhythmically laminated green and white couplets with occasional intervening thin turbidite marlstone beds. As described below, the microfabric of the green laminae consists of a huge accumulation of centric diatoms, mainly Cyclotella species (L. Benda, personal commun., 1994), whereas the white ones are formed of a mixture of tiny calcite-aragonite crystals and diatom frustules. The colour differentiation between the laminae is clearly observed in very fresh outcrops that after a few months of exposure become white, giving the characteristic aspect of diatomite.

Both the laminated marlstones and the interbedded laminite sequences are facies characteristic of sedimentation in profundal ('basinal') lake areas. Good preservation of the laminites

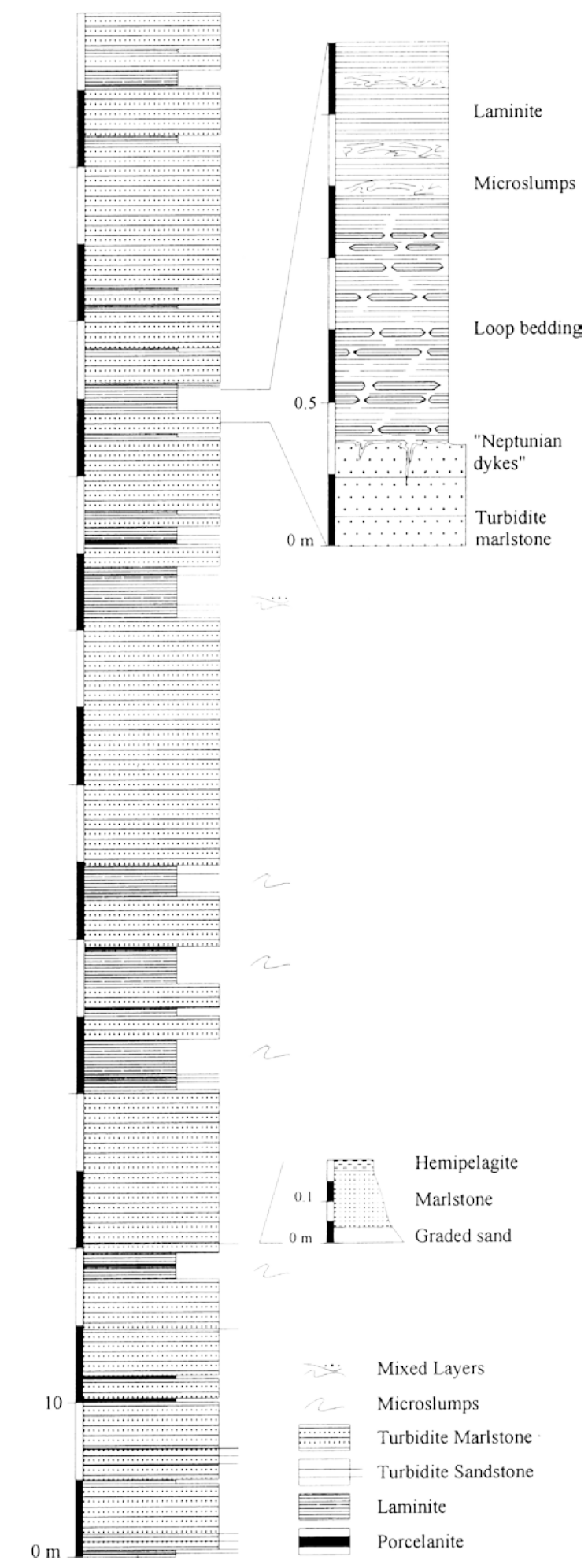

Fig. 2. Partial log of measured stratigraphic section from the Late Miocene succession in H1jar. Detailed log in the lower part of the section shows one of the typical turbidite sequences observed within the lacustrine marlstones. The log inserted at the upper right side sketches the loop bedded laminite sequence described in this paper. 
and the complete absence of bioturbation within the two lithofacies indicate that the lake was permanently stratified, favouring anoxic conditions at the lake bottom (Kelts \& Hsu, 1978; Anderson \& Dean, 1988). Lake water stratification was probably thermally-induced although the presence of a significant amount of aragonite in the laminite sequences could be also indicative of moderately high saline conditions resulting in chemical stratification of the bottom lake waters. Organic productivity in the lake was high as indicated by the large amount of diatoms as well as by high oil contents, determined from drill hole samples (ITGE, 1993). Quiescent conditions on the lake floor were often altered by turbid underflows that introduced abundant detrital sediment into the deeper lake areas. In spite of the small extent of the Hijar Basin, most of the sediment supplied by the turbidite flows has an intrabasinal origin. The only traces of extra- basinal grains are represented by coarser grained sandstones (mainly Mesozoic carbonate grains) as a thin lens in the basal part of very few turbidite beds. Scattered clay grains are also recognized within the marlstone. On the other hand, occa- sional accumulations of plant remains in dark layers at the top of the marlstone beds may be interpreted as hemipelagite within the turbidite sequences.

The great thickness of basinal facies in H1jar suggests that this basin behaved as a rapidly subsiding trough in which the subsidence and sedimentation rates were more or less equilibrat- ed throughout a long time interval. Frequent resedimentation processes, as marked by the abundant turbidite deposits, are indicative of active tectonism rather than instability related to high growth of the carbonate lake platforms. Evidence of tectonic activity is also provided by local resedimentation of the laminites resulting in the formation of microslumps at several levels in the lacustrine succession (Fig. 2). The thickness of the slumped beds ranges from a few millimetres to $4 \mathrm{~cm}$. 'Mixed layers', i.e. internally disturbed beds as a result of seismogenic shaking (Marco \& Agnon, 1995), have also been observed at several levels of the lacustrine succession in the Hljar Basin. The mixed layers consist of basal folded strata which show gradual upward transi- tion through a laminite fragmentsupported tex- ture to a matrix-supported texture at the top. Thickness of the individual mixed layers ranges from 2 to $9 \mathrm{~cm}$. Each layer formed because of shaking induced by earthquakes of moderate to high intensity, the seismic shock accounting for hydroplastic deformation of the lower bed lami- nae and fluidization plus partial resuspension of the bed top (Marco \& Agnon, 1995; Rodrlguez- Pascua et al., 1996). Besides these types of deformational structures, the presence of loop bedded laminites constitutes an outstanding feature within some beds in the lacustrine succession in the Hijar Basin.

\section{LOOP BEDDING DESCRIPTION AND INTERPRETATION}

In a very well-exposed outcrop located towards the upper part of the H1jar succession the loop bedded laminites mainly occur in both the lower and middle parts of a 1.40 m-thick, rhythmically laminated bed (Fig. 2). The laminite sequence overlies thicker bedded marlstones that display a light-brown colour and are internally massive to slightly graded. The contact between the lam- inites and the marlstones is sharp (Fig. 3A). A closer view of the contact shows that the marl- stone is traversed by fissures that extend up to $30 \mathrm{~cm}$ from the marlstone top downwards. The width of the fissures reaches a maximum of $6 \mathrm{~cm}$ at the top. In cross-section the fissures are spaced out laterally from $25 \mathrm{~cm}$ to a few metres, the uppermost part of the single fissures being marked by a concave morphology in which laminites from the overlying bed have flowed downwards and rest either as normally folded laminae or strongly deformed material filling the hole (Fig. 3B). The fissures are also filled by massive, reworked marlstone below the folded laminites.

Except for some thin marlstone intercalations towards the basal part of the laminites, the laminites comprise a rhythmic alternation of dark green and white laminae whose respective thicknesses vary from couplet to couplet, so giving the appearance of stacked light and dark layers upward across the bed (Fig. 3C). In this way, the laminite bed comprises separate layers that are defined by a higher frequency of white laminae and others where the green laminae are predominant. Loop bedding, i.e. the constriction of groups of laminae at lateral intervals, is clearly related to the layers in which white laminae predominate, both the overlying and underlying green laminae being accommodated within the loop space (Fig. 3D). The thickness of the predominantly white layers ranges typically from 8 to $15 \mathrm{~mm}$ and the loops end laterally at decimetric intervals. A close-up view of the loop bedded laminite reveals a variety of microdeformational features 

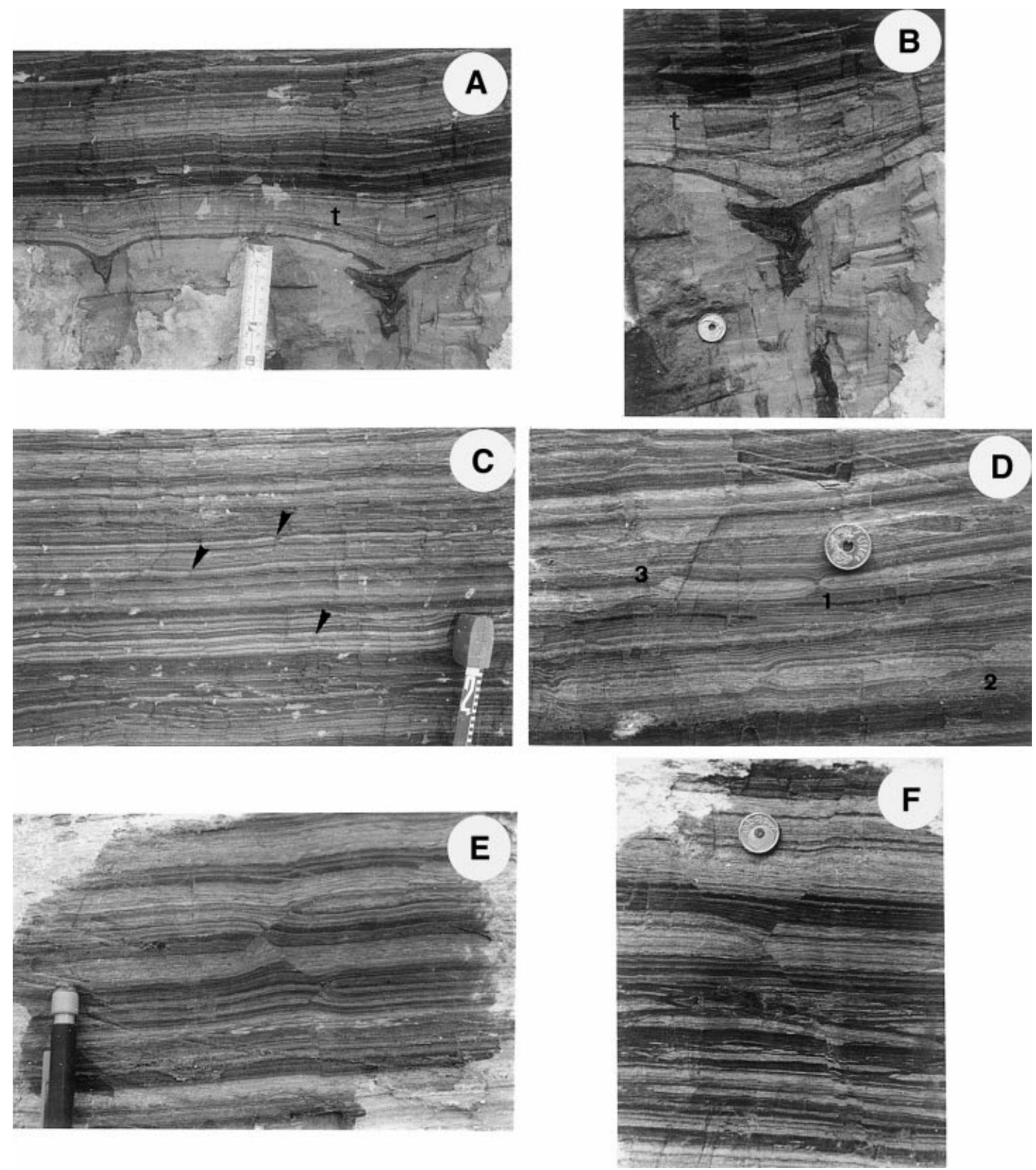

Fig. 3. Outcrop views of the laminite sequence and underlying marlstone. (A) Contact between marlstone and laminites; the contact is sharp and displays an undulating geometry with fissures spaced out at decimetric intervals; numbered square in the staff is $10 \mathrm{~cm}$. (B) Closer view of one of the fissures showing strongly contorted laminites that partly infill the fissure; though not well contrasted on the photograph, the lowermost part of the fissure is filled by reworked marlstone; ' $t$ ' represents a thin turbidite marlstone layer intercalated at the base of the laminite sequence (see text for explanation). (C) Rhythmic alternation of dark green and white laminae within the laminite deposit; arrows point the location of some loop ends; minor divisions in the staff are in centimetres. (D) Close-up view of loop bedding in the laminites; numbers correspond to the several types of loop described in text. (E) Close-up view of loops of type 4; the photograph covers an area of $7 \times 12 \mathrm{~cm}$. (F) Small scale faults showing local roll-over geometries; the faults cut bundles of laminae which display previous deformational features. Coin diameter in (B)-(D)-(F) is 2 c

which may be classified in the following manner (Fig. 3; see also Fig. 6 for sketch representation of the loop types): (a) Simple loops. They show a typical 'boudin' morphology without intervening fractures. Two types of simple loops have been differentiated: 
Type 1, which constitutes the most simple structure as it comprises bundles of laminae bending symmetrically on both sides of the boudin neck (see example in Fig. 3D); thus it contains the symmetry plane which is typically perpendicular to the lamination. The thinner green laminae are folded in both the upper and lower parts of the boudin neck. Type 2 does not show such a defined pattern as the laminites adjacent to the boudin neck are disaggregated, resulting in an asymmetrical loop morphology (see example also in Fig. 3D).

(b) Complex loops. In this category, the boudin necks are traced by normal microfaults that start and end within the layers of the laminite bed. The throws of the fractures are commonly low, usually ranging from 2 to $4 \mathrm{~cm}$. According to the microfault patterns involved in the disruption of laminae, two types of complex loops have been differentiated: Type 3, formed of bundles of laminae which are disrupted and constricted by single fractures; in each loop, the fracture behaves as a weakness plane, the resulting space being filled by sliding laminae that fill and underline the boudin neck. Type 4: in this case, the constriction of the bundles of laminae is due to systems of conjugated microfaults which show the same direction but opposite dips (Fig. 3E); both the laminae that overlie and underlie the loop are commonly deformed because of the infill of the space created extensionally.

In addition to the microdeformational features represented by loops, longer faults, reaching several tens of centimetres, that cut the loop bedded laminites have been observed in the outcrop. These faults show a relatively complicated pattern with local roll-over geometries (Fig. 3F).

\section{Microfabrics of laminites and associated sediments}

SEM study of the laminites reveals a significant difference between the microfabrics of the green and white laminae. SEM was also performed on the brownish marlstone sediment affected by fissures that underlies the laminite sequence. As described above, this marlstone is also present as intercalated thin layers between the laminites, especially in the lowermost part of the laminite sequence. Distinction of the microfabric features displayed by these three main lithofacies is relevant in order to interpret their deformational behaviour.
Under SEM, the green laminae are seen to be formed of a tight aggregate of roughly orientated diatom frustules (Fig. 4A). The diatoms are almost exclusively centric with two morphological types of Cyclotella species. The size of the diatoms is very similar for all the specimens averaging $10 \mu \mathrm{m}$ in diameter. In detail, some frustules exhibit slight corrosion and breakdown of the areolae similar to the dissolution phenomena observed in diatoms of very recent lake sediments (Alefs \& Muller, 1995). By contrast, the white laminae are composed of a mixture of smaller centric diatoms and minute rhombohedral calcite crystals with minor aragonite. The percentage of the diatom frustules within the white laminae is variable but rarely exceeds $40 \%$ (Fig. 4B). The calcite crystals, especially the smaller ones, form aggregates that give a relatively consolidated appearance to this fabric. The marlstone displays a more disorganized fabric formed of diatom frustules, both centric and elongated, calcite and aragonite crystals of variable size, and scattered clay grains. The diatom frustules are mostly corroded and the carbonate crystals also form local aggregates.

\section{Microdeformational analysis}

We carried out systematic measurement of the directions of the loop axes in laminites and the fissure planes developed within the underlying marlstone in the outcrop. A total of 62 loop axes were measured on the lamination planes after picking orientated samples from the outcrop. Twenty eight measurements of the directions of the fissure planes were made directly in the outcrop. The measured orientations of the loop axes have been plotted on a stereo net for representation of the main structural contours. Additionally, the data were also represented as rose diagrams (Fig. 5A). These diagrams show that the loop axes are distributed according to two main directions: $005^{\circ}$ (predominant) and $105^{\circ}$, this is, quasi-perpendicular. Plotting of the fissure planes on a stereo net and the derived rose diagram (Fig. 5B) shows that the directions of the planes are distributed in two modes, the main one of $350^{\circ}$ and other subordinate of $100^{\circ}$. Thus, the diagrams show that the main modes for both loop axes and fissure plane directions fall within very close fields. In turn, these are almost parallel to the normal faults that delimit the Hljar Basin (Fig. 1C), thus suggesting a similar tectonic behaviour at different scales. 

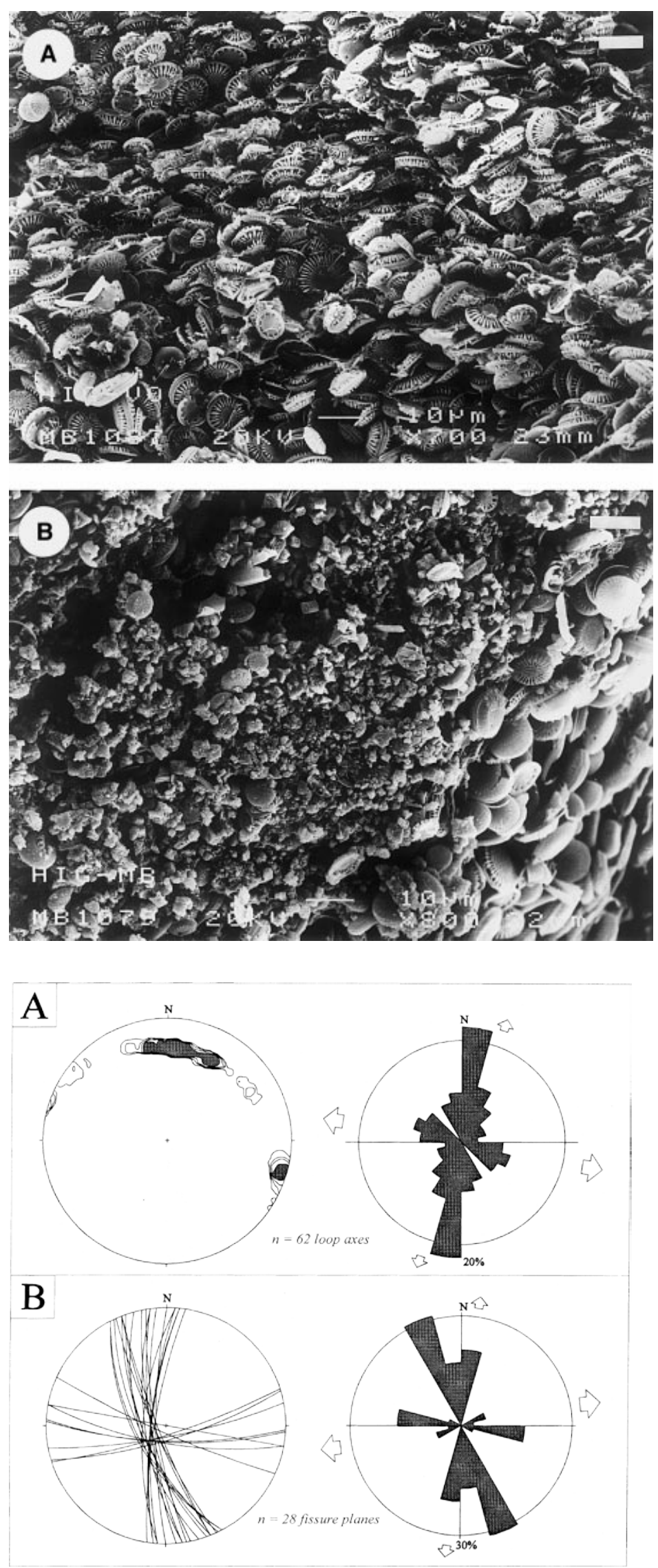

Fig. 4. Microfabrics of laminites and associated sediments seen under SEM. (A) Densely-packed aggregate of centric diatoms (Cyclotella species) which forms the fabric of the dark green laminae. Scale bar $10 \mu \mathrm{m}$. (B) SEM view of the limit between dark green (right) and white laminae, the former showing a huge accumulation of centric diatoms whilst the latter comprise a mixture of tiny carbonate crystals and diatom frustules. Scale bar $10 \mu \mathrm{m}$.

Fig. 5. Representation of data derived from microdeformational analysis of the loop bedded laminites and underlying marlstone. (A) Contour and rose diagrams resulting from plotting on a stereo net of the measured orientations of loops (class intervals $10^{\circ}$ ). (B) Stereo net projection of the plane directions (class intervals $10^{\circ}$ ) determined in fissures and its derived rose diagram. In both rose diagrams, arrows point out the average extension directions indicated by the modes of loop axes (A) and fissure planes (B). The principal extension directions are represented by the largest arrows. 


\section{Interpretation of deformational features}

The microdeformational analysis of the loop bedded laminites and the fissured underlying marlstone suggests that the two kinds of features are genetically related. The main modes determined for loop axes and fissure planes lie approximately in a N-S direction which indicates that they form in response to prevailing E-W tensional stresses (Fig. 5). As discussed below, this interpretation assumes that both the loop bedding and the fissures represent extensional deformation structures formed where the tensile strength of the deposits is exceeded (Collinson, 1994).

\section{Formation of fissures in marlstone}

Fissures developed at the contact between the marlstones and the laminite sediments are filled partly by deformed laminites which clearly indicates that the opening of the fissures started soon after the deposition of the lowermost laminites. Moreover, these laminites were unlithified or very poorly lithified at the time the fissures opened, as indicated by their strongly contorted geometry within the fissures (Fig. 3B). These observations follow the basic pattern deduced for the formation of neptunian dykes, a sedimentary structure consisting of a dyke in which the infilling sediments are derived from above, in contrast to some sedimentary dykes with fill injected from below (Winterer \& Sarti, 1994). Neither the scale nor the undersea nature of the sediments that are typically associated with neptunian dykes (e.g. in the passive continental margins of the Mesozoic Tethys in the circumMediterranean region; Wendt, 1971) are represented in the H1jar deposits but, besides the basic infill pattern of the fissures, two aspects must be compared: (i) both the opening and the infill of the fissures were realized in a subaqueous envir- onment as evidenced by the lack of any feature indicative of subaerial exposure; (ii) both the morphology of the fissures and their distribution along the top of the marlstone (Fig. 3A) strongly suggest that they formed in response to tensional stress, which is also characteristic of the origin for neptunian dykes (Winterer et al., 1991; Vera, 1994).

The straight geometries of the dykes are characteristic of brittle fracturing of the marlstone, thus suggesting that the deposit was partly or totally consolidated at the time the fractures opened. Very likely, the consolidation rate of the marlstone decreased from bottom to top. After the opening and rapid infill of the dykes by laminites, a thin turbidite marlstone bed (marked ' $t$ ' in Fig. 3A \& B) which laterally grades into slumped laminites was deposited. The thickest parts of this bed are located over the depressions created by the dykes and the turbidite top shows gentle concave geometries above the dykes, which indicates that the fissure was dilated over a relatively long time interval.

According to these observations, the formation of the dykes is interpreted to be related to successive microseismic shocks taking place in a tensional tectonic context. These seismic shocks would account for stretching of the partly lithified marlstone bed and further opening and infill of the fissures by previously deposited thin laminite packages. Also the deposition of some marlstone turbidites in the lowermost part of the overlying laminite sequence could be related to these seismic events. This pattern of successive microseismic shocks resulted from generalized dilational creep movement of the faults that limit the basin, as deduced from the similar directions of the fissure planes and the faults.

\section{Formation of loop structures}

Simple loops represent deformational structures that resulted from purely ductile deformation. The term 'ductile' is used here as equivalent to plastic (see Maltman, 1994, for comments about the terminology used for deformational processes). The shapes of the simple loops, especially those of type 1, closely resemble 'boudinage' (Ramsay, 1967; Ramsay \& Huber, 1983), the 'boudins' resulting from the stretching of alternating beds where the competence contrast is not strongly marked ('pinch and swell structures' of Ramsay \& Huber, 1983). In our case, the constriction of laminae leading to the geometry of loops mainly developed in bundles of predominant white laminae that behaved as a more competent material because of their relatively higher rate of lithification contributed by cementing calcite crystals (Fig. 4B). In this pattern, the green laminae behaved as an incompetent matrix, flowing and thickening towards the boudin necks. This behaviour was favoured by the loose internal fabric of the green laminae which consist chiefly of discoid diatom skeletons (Fig. 4A). Moreover, the facility of these laminae to flow could be also related to the presence of a significant amount of organic matter within the diatomites of the H1jar Basin (ITGE, 1993) 
which would act as an effective lubricating agent. Simple loops of type 2 show a rather similar pattern but disaggregation in the form of contor- tion and occasional breakage of the laminae below the boudin necks suggests that the ten- sional stress affected laminae that were somewhat more lithified.

In contrast, complex loops are characterized by the presence of microfaults that limit the bundles of laminae, the difference between types 3 and 4 being related to the complexity of the microfault system as well as the behaviour of the laminae adjacent to the disruption zones. This suggests that the deformation developed in relatively welllithified laminites where the loss of strength was reduced and consequently the tensional stress moved beyond the ductile deformational field (Owen, 1987). The resulting structures closely resemble typical 'boudinage' (Ramsay \& Huber, 1983) as the ends of the more competent layers display sharp contacts with the associated laminae. An effect of disaggregation of the laminae adjacent to the boudin necks is locally observed, which suggests significant competence contrasts between the layers at the time of the deformation.

Longer faults occur both in otherwise undeformed laminae as well as in association with previously deformed layers showing loop bedding or microslumps. Except for some local examples where the disruption of the bundles of laminae results in apparent loop morphologies (Fig. 3F), the fractures are sharp, suggesting that the competence contrasts between laminae had been eliminated, and furthermore the related deformation is clearly included in the brittle deformational field. The arrangement of smallscale faults in the outcrop resembles that observed by Hesselbo and Trewin (1984) in Carboniferous, lagoonal thin-laminated sediments from the Granton 'shrimp bed'. Maltman (1988) interpreted this type of faults as related to extensional tectonics that parallel structures caused by regional extension.

An integrated view of the distribution of simple loops, complex loops and small-scale faults throughout the laminite bed lead us to conclude that this set of deformational features formed as a

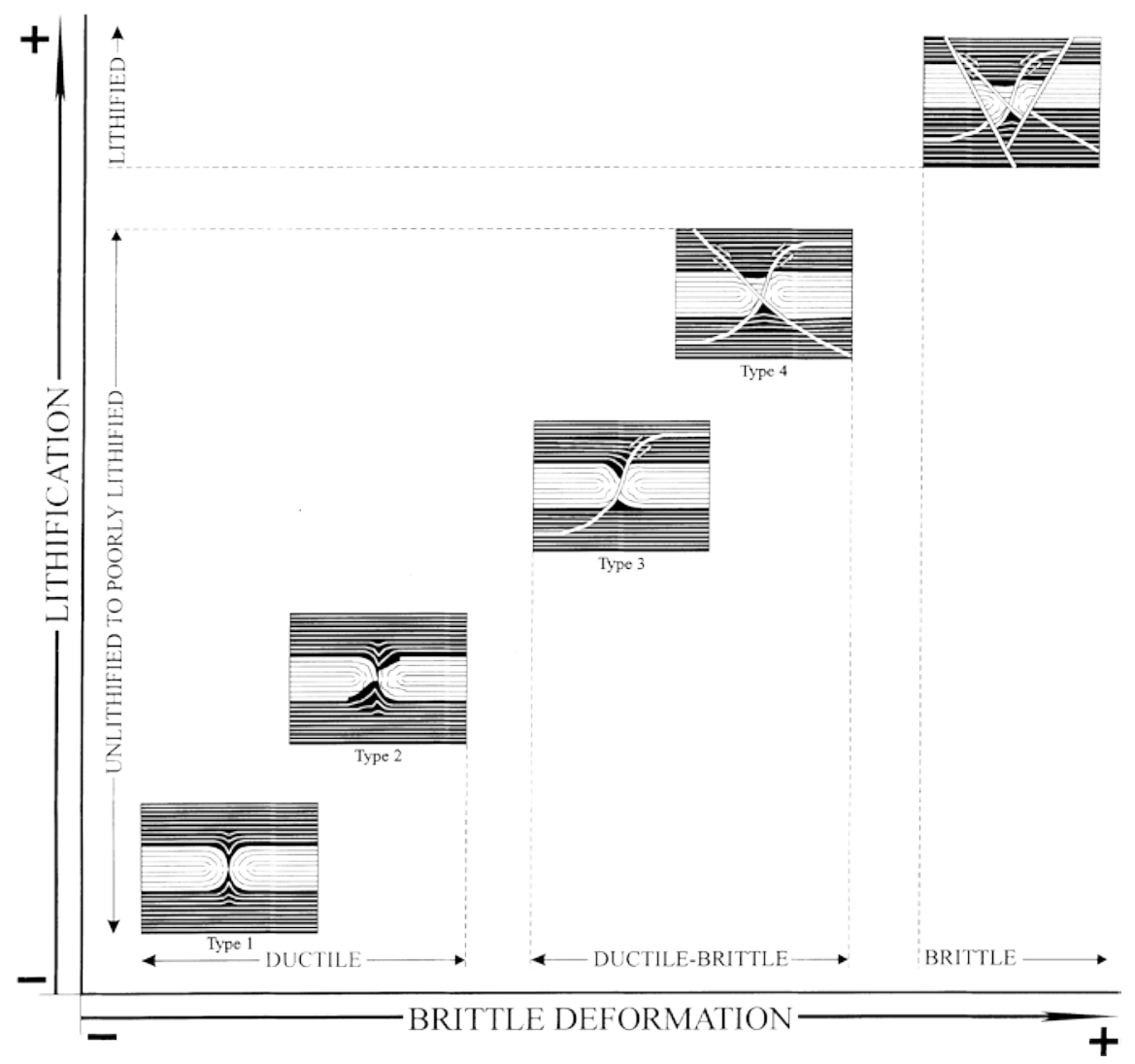

Fig. 6. Integrated model for the formation of the different types of loops recognized within the laminite sequence. The model highlights the control of progressive lithification in the deformational style of the laminites (see further explanation in text). 
Fig. 7. The pattern of 'chocolate tablet boudinage' which resulted from sub-perpendicular extension directions. The sketch should be applied exclusively to loops of type 1 ('pinch and swell boudinage') typical of purely ductile deformation.

continuum of events, reflecting interplay between progressive lithification of the laminites and maintained extensional stresses affecting the sediment sequence. The tectonic movements were transmitted to the sediment as successive microseismic shocks. The unlithified bundles of laminae were subject to purely ductile deformation (simple loops of type 1) (Figs $6 \& 7$ ). As the lithification progressed, tectonic stress resulted in the formation of loops characterized by ductile to brittle deformation (loops of types 2, 3 and 4). Thus, the morphological differences displayed by the loops were mainly due to the gradual variation in the lithification state of the laminites evolving under the influence of rather uniform, deep-seated tectonic stresses. This interpretation is plausible to explain the occurrence of distinct types of loops along the same layer, as well as the fact that loop bedding occurs at various levels in the laminite sequence. The larger faults that cut previous deformational structures probably reflect a later brittle stage of deformation, which probably developed after the whole laminite sequence had accumulated.

\section{DISCUSSION}

Fine-grained, thinly laminated sediments, whether of lacustrine or marine origin, are considered an excellent natural laboratory for studying processes of sediment accumulation in a given basin. In particular, rhythmically laminated sequences deposited in lakes offer one way to trace a high resolution history of the accumulation, preservation, and further modification of the primary lake deposits (Glenn \& Kelts, 1991). Likewise, distur-

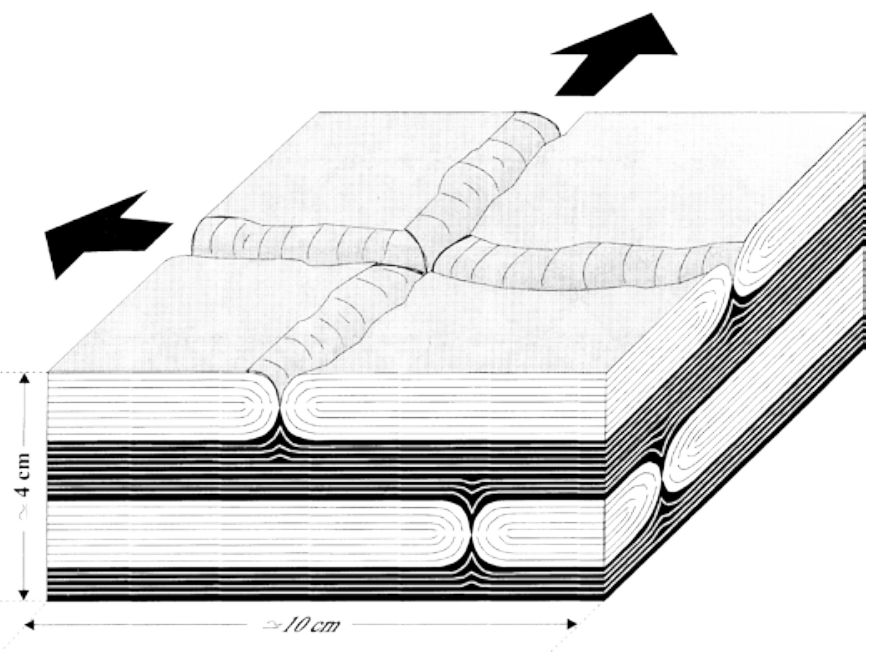

bances produced by tectonic events contemporaneous with the infill of the lake basins are commonly well registered within the sedimentary sequences and, furthermore, the recognition of these disturbances and their possible recurrence rates through the stratigraphic successions may help in reconstructing the tectonic evolution of the basins. Although a complete catalogue of sedimentary structures related to seismic events (i.e. seismites, Seilacher, 1984), is still missing for sequences deposited in lakes, the documentation of this topic has considerably increased lately (Sims, 1973, 1975; Hempton \& Dewey, 1983; Scott \& Price, 1988; Doig, 1991; Marco \& Agnon, 1995). According to observations of both recent and ancient lake sequences, a variety of structures encompassing deformed layers of soft sediment has been attributed to earthquakes. These structures include dykes, some convolute morphologies, pseudo-nodules, ball and pillow, slumps of varied scale, synsedimentary faults and mixed layers, which are interpreted to be caused by either fluidization or liquefaction (Lowe, 1976; Allen, 1982; Seilacher, 1984; Maltman, 1994). The magnitude of the earthquakes at which the seismites form is still a matter of debate though there is current consensus that liquefaction and fluidization of both cohesive or cohesiveless sediments may occur at a magnitude greater than 4.5 (Marco \& Agnon, 1995). These authors have provided strong evidence that surface faults caused by earthquakes develop at magnitude (M) equal or higher than 5.5. These results were derived from detailed analysis of seismically induced deformational structures, i.e. mixed layers, in laminated deposits from the Pliocene Lisan Formation, Israel. These deposits represent a 
good example of the sedimentary infill of quietwater basins and allow comparison with those observed in the H1jar Basin.

Laminite beds in the H1jar Basin display microslumps and mixed layers at several levels of the lacustrine succession (Fig. 2). The occurrence of these structures, especially mixed layers, within the laminated sediments has been interpreted to result from seismic shaking which, according to Marco \& Agnon (1995), would represent earthquakes stronger than M 5.5 (Rodrlguez-Pascua et al., 1996). Detailed analysis of the cyclicity shown by the mixed layers within one laminite bed in the H1jar Basin revealed a recurrence rate of about $120 \mathrm{yr}$ for the seismic events that originated the mixed layers, these repetitive events being typically separated by periods of relative quiescence (Rodrlguez-Pascua et al., 1996). Both the occurrence of mixed layers and microslumps within some laminite beds and the wide presence of marlstone deposited as turbidites are clearly indicative of the unstable tectonic conditions that prevailed during the sedimentary infill of the H1jar Basin throughout the Late Miocene. The recognition of loop bedding and underlying fissures in the case study laminites described above fits well this pattern of tectonic unstability. Yet the develop- ment of loop bedding is thought to reflect weak, repetitive seismic shocks affecting the layers while they were subject to changing lithification as sedimentation progressed, which is in con- trast with the higher magnitude of earthquakes inferred from the occurrence of mixed layers in other laminite beds throughout the Miocene succession. As deduced from both macro- and microdeformational analyses (Figs 1C \& 5), the stretching of the laminites was sub-perpendicular to extension directions and the resulting boudin necks of the loop structures are arranged in a well defined, rather regular pattern (Fig. 7) quite comparable to the so-called 'chocolate tablet boudinage' of Ramsay \& Huber (1983, page 65).

These results are partly in agreement with those obtained by Hesselbo and Trewin (1984) from Carboniferous laminated sediments in Scotland though the higher regularity of the loop geometries in the H1jar laminites and their alignment in consistent directions suggest that they formed under quieter, deep-seated tectonic stresses. This interpretation precludes consideration of loop bedding as a structure caused by synaeresis or other mechanisms of shrinkage related to purely sedimentary processes.

\section{CONCLUSIONS}

The recognition of loop bedding in laminite sediments from Late Miocene lacustrine formations of SE Spain supports a detailed analysis of this type of structure which has been previously observed, but not thoroughly interpreted, in finegrained laminated sediments elsewhere. In the case study, loop bedding developed within laminite sediments comprising a rhythmic alternation of dark green, diatom-rich laminae and white laminae in which diatoms are mixed with a varied amount of carbonate. The constriction of laminae at lateral intervals which characterizes the loop structures is observed to affect mainly bundles of white laminae, probably because of their higher competence relative to the dark ones. Four types of loops have been recognized. Loops of type 1 constitute the most simple structure which formed as a response to purely ductile deformation. Loops of type 2 show disaggregation of the laminae close to the boudin necks, suggesting that they were somewhat lithified when subject to deformation. Types 3 and 4 are considered complex loops which display microfaults at the end of the bundles of laminae, so being indicative of brittle deformation where the laminae were more indurated. Finally, longer faults, reaching several tens of centimetres, cut the loop bedded laminites and are interpreted as reflecting a later stage of purely brittle deformation.

The distribution of the various loop types across the laminites reflects interplay between progressive lithification as sedimentation progressed and the tectonic stresses reached in the sediment sequence. The directions determined both for loop axes and fissures developed in marlstone beds underlying the laminites are consistent and show similar values to those measured in the main faults that limit the basin. This provides evidence that the deformation resulting in loop bedding was consistent with the general extensional stress field in which the basin evolved. Thus, in the case study, loop bedding is interpreted as a result of the stretching of unlithified to progressively more lithified laminated sediments in response to successive minor seismic shocks, ultimately related to the creep movement of extensional faults. Comparison of these structures with other seismicallyinduced deformational features throughout the lacustrine succession points toward the use of loop bedding as an indicator of low magnitude 
seismic activity in active subsiding basins dom- inated by tensile stress.

\section{ACKNOWLEDGMENTS}

We thank J. Parnell, K. Kelts and M. Talbot for their suggestions and information about loop bedding occurrences in lacustrine formations. L. Benda provided diatomological expertise. J. Sanchez prepared the photographs. We are also indebted to A. M. Alonso Zarza, J. P. Rodriguez and A. Borruso who helped in field work.

J. Parnell provided a number of useful comments in reviewing the paper and B. G. Jones greatly improved the final version of the manuscript. This work has profited from the financial support of the CICYT Project AMB94-0994 and has been partly funded by a grant of the 'Consejo de Seguridatd Nuclear' of Spain to one of the authors (M.R.P).

\section{REFERENCES}

Alefs, J. and Muller, J. (1995) Diatom stratigraphy and frustule dissolution in varved sediments of Lake "Ammersee" (Bavaria, Germany). First Intern. Limno-geological Congress, Copenhaguen, Abstracts, 5.

Allen, J.R.L. (1982) Sedimentary Structures: their Character and Physical Basis. Developments in Sedimentology 30A \& B. Elsevier Publ. Co., Amsterdam, 1258 pp.

Anderson, R.Y. and Dean W.E. (1988) Lacustrine varve formation through time. Palaeogeogr., Palaeoclim., Palaeoecol., 62, 215-236.

Bates, R.L. and Jackson, J.A. (1980) Glossary of Geology. Amer. Geol. Inst., Falls Church, Virginia, 751 pp.

Bellanca, A., Calvo, J.P., Censi, P., Elizaga, E. and Neri, R. (1989) Evolution of lacustrine diatomite-carbonate cycles of Miocene age, Southeastern Spain: petrology and isotope geochemistry. f. sedim. Petrol., 59, 4552.

Bellon, H., Bizon, G., Calvo, J.P., Elizaga, E., Gaudant, J. and López-Mart'lnez, N. (1981) Le volcan du Cerro del Monagrillo (Province de Murcia): Age radiométrique et corrèlations avec les sédiments néogènes du bassin de Hellin (Espagne). C.R. Acad. Sc. Paris, 292, 1035-1038.

Bradley, W.H. (1931) Origin and microfossils of the oil shale of the Green River Formation of Colorado and Utah. U.S. Geological Survey Prof. Paper 168, 58 pp.

Buatois, L.A. and Mángano, M.G. (1995) Sedimentary dynamics and evolutionary history of a Late Carboniferous Gondwanic lake in norht-western Argentina. Sedimentology, 42, 415-436.

Calvo, J.P. and Elizaga, E. (1994) The Cenajo and Las Minas-Camarillas basins (Miocene), southeastern Spain. In: Global Geological Record of Lake Basins, Vol. 1 (Ed. by E. Gierlowski-Kordesch and K. Kelts), pp. 319-324. Cambridge Univ. Press.
Calvo, J.P., Elizaga, E., Lòpez-Marthez, N., Robles, F. and Usera, J. (1978) El Mioceno superior continental del Prebético Externo: Evolución del Estrecho Nordbético. Bol. Geol. Minero, 89, 407-426.

Cole, R.D. and Picard, M.D. (1975) Primary and secondary sedimentary structures in oil shale and other fine grained rocks, Green River Formation (Eocene), Utah and Colorado. Utah Geology, 2, 49-67.

Collinson, J. (1994) Sedimentary deformational structures. In: The Geological Deformation of Sediments (Ed. by A. Maltman), 95-126. pp. Chapman \& Hall, London.

Dean, W.E. and Fouch, T.D. (1983) Lacustrine Environment. In: Carbonate depositional environments (Ed. by P.A. Scholle, D.G. Bebout and G.H. Moore), Amer. Assoc. Petr. Geol., Mem. 33, 97-130.

Doig, R. (1991) Effects of strong seismic shaking in lake sediments, and earthquake recurrence interval, Ténniscanning, Quebec. Can. f. Earth Sci., 28, 13491352.

Donovan, R.N. (1975) Devonian lacustrine limestones at the margin of the Orcadian Basin, Scotland. Q. fl. geol. Soc. London, 131, 489-510.

Donovan, R.N. and Foster, R.J. (1972) Subaqueous shrinkage cracks from Caithness Flagstone Series (middle Devonian) of northeast Scotland. f. sedim. Petrol., 42, 309-317.

Elizaga, E. (1994) Análisis de facies sedimentarias y petrologla de los depósitos lacustres de edad $\mathrm{Ne}$ ógeno superior de la Zona Prebética, Albacete, Espara. Inst. Est. Albacetenses, Albacete, 216 pp.

Fregenal-Mart'hez, M.A. and Melèndez N. (1994) Sedimentological analysis of the Lower Cretaceous lithographic limestones of the 'Las Hoyas' fossil site (Serranla de Cuenca, Iberian Range, Spain). Geobios, 16, 185-193.

Gibling, M.R., Tantisukrit, C., Uttamo, W., Thanasuthipitak, T. and Haraluck, M. (1985) Oil shale sedimentology and geochemistry in Cenozoic Mae Sot Basin, Thailand. Amer. Assoc. Petr. Geol. Bull., 69, 767-780.

Glenn, C.R. and Kelts, K. (1991) Sedimentary rhythms in lake deposits. In: Cycles and Events in Stratigraphy (Ed. by G. Einsele, W. Ricken and A. Seilacher), pp. 188-221. Springer-Verlag, Berlin.

Hempton, M.R. and Dewey, J.F. (1983) Earthquake-induced deformational structures in young lacustrine sediments, East Anatolian Fault, southeast Turkey. Tectonophysics, 98, 7-14.

Hesselbo, S.P. and Trewin, N.H. (1984) Deposition, diagenesis and structures of the Cheese Bay Shrimp Bed, Lower Carboniferous, East Lothian. Scott. $f$. Geol., 20, 281-296.

Instituto Tecnologico Geominero de Espan a (1993) Investigación de diatomitas en el Sur de Albacete. Unpubl. Report, Instituto Tecnológico Geo-Minero de Espara, Madrid, 6 vols.

Kelts, K. and Hsu, K.J. (1978) Fresh-water carbonate sedimentation. In: Lakes - chemistry, geology, physics (Ed. by A. Lerman), pp. 295-323. Springer-Verlag, New York.

Lowe, D.R. (1976) Subaqueous liquified and fluidized sediment flows and their deposits. Sedimentology, 23, 285-308. 
Maltman, A. (1988) The importance of shear zones in naturally deformed wet sediments. Tectonophysics, 145, 163-175.

Maltman, A. (Ed.) (1994) The Geological Deformation of Sediments. Chapman \& Hall, London, 362 pp.

Marco, S. and Agnon, A. (1995) Prehistoric earthquake deformations near Masada, Dead Sea Graben. Geology, 23, 695-698.

Ozalas, K., Savrda, C.E. and Fullerton, R.R.Jr. (1994) Bioturbated oxygenation-event beds in siliceous facies: Monterey Formation (Miocene), California. Palaeogeogr., Palaeoclim., Palaeoecol., 1 12, 63-83.

Owen, H.G. (1987) Deformation processes in unconsolidated sands. Geol. Soc. London Spec. Publ., 29, 11-24.

Ramsay, J.G. (1967) Folding and Fracturing of Rocks. McGraw-Hill, New York, 568 pp.

Ramsay, J.G. and Huber, M.I. (1983) The Techniques of Modern Structural Geology. Vol. 1: Strain Analysis. Academic Press, London, 307 pp.

Rayner, D.H. (1963) The Achanarras limestone of the Middle Old Red Sandstone, Caithness, Scotland. Proc. Yorks. Geol. Soc., 34, 117-138.

Rodrlguez-Pascua, M.A., De Vicente, G., Ram'lrezRayo, M.S., Mart'ln-Velázquez, S. and Calvo, J.P. (1996) Periodos de recurrencia de paleoterremotos en sedi- mentos varvados lacustres del Mioceno superior, Cuenca de H1jar (Albacete). Geogaceta, 20, 1004- 1007.

Sanz de Galdeano, C. and Vera, J.A. (1992) Stratigraphic record and palaeogeographical context of the Neogene basins in the Betic Cordillera, Spain. Basin Research, 4, 21-36.

Scott, B. and Price, S. (1988) Earthquake-induced deformational structures in young sediments. Tectonophysics, $147,165-170$.

Seilacher, A. (1984) Sedimentary structures tentatively attributed to seismic events. Mar. Geol., 55, 1-12.
Sims, J.D. (1973) Earthquake-induced structures in sediments of Van Norman Lake, San Fernando, California. Science, 182, 161-163.

Sims, J.D. (1975) Determining earthquake recurrence intervals from deformational structures in young lacustrine sediments. Tectonophysics, 29, 141-152.

Sturm, M. and Matter, A. (1978) Turbidites and varves in Lake Brienz (Switzerland): deposition of clastic detritus by density currents. Spec. Publs int. Ass. Sediment., 2, 145-166.

Trewin, N.H. (1986) Palaeoecology and sedimentology of the Achanarras fish bed of the Middle Old Red Sandstone, Scotland. Trans. R. Soc. Edinburgh, Earth Sci., 77, 21-46.

Van der Beek, P.A. and Cloethingh, S. (1992) Lithospheric flexure and the tectonic evolution of the Betic Cordilleras (SE Spain). Tectonophysics, 203, 325344.

Vera, J.A. (1994) Estratigraf1a. Principios y métodos. Editorial Rueda, Madrid, 802 pp.

Wendt, J. (1971) Genese und fauna submariner sedimenta rer Spaltenfu llungen in mediterranen Jura. Palaeontographica A, 136, 122-192.

Winterer, E.L. and Sarti, M. (1994) Neptunian dykes and associated features in southern Spain: mechanics of formation and tectonic implications. Sedimentology, 41, 1109-1132.

Winterer, E.L. Metzler, C.V. and Sarti, M. (1991) Neptunian dykes and associated breccias (Southern Alps, Italy and Switzerland): role of gravity sliding in open and closed systems. Sedimentology, 38, 381404. 